\title{
Role of Unani Medicine in the Management of Palpitation
}

\section{Usama Akram $^{1 *}$, Neelam Quddusi ${ }^{1}$, Azma Waseem ${ }^{1}$, Zaki Ahmad Siddiqui $^{2}$ and M Fazil ${ }^{3}$}

${ }^{1}$ Research Officer, Hakim Ajmal Khan Institute for Literary and Historical Research in Unani Medicine, CCRUM, Ministry of AYUSH, Government of India, India ${ }^{2}$ Research Officer, CCRUM Headquarters, Ministry of AYUSH, Government of India, India

${ }^{3}$ Head of Institute, Hakim Ajmal Khan Institute for Literary and Historical Research in Unani Medicine, CCRUM, Ministry of AYUSH, Government of India, India

*Corresponding Author: Usama Akram, Research Officer, Hakim Ajmal Khan Institute for Literary and Historical Research in Unani Medicine, CCRUM, Ministry of AYUSH, Government of India, India.
Received: April 25, 2020

Published: May 12, 2020

(c) All rights are reserved by Usama Akram., et al.

\begin{abstract}
As per World Health Organization (WHO) the heart palpitations are the feelings of having a fast-beating, fluttering or pounding heart. In rare cases, they can be a symptom of a more serious heart condition, such as an irregular heartbeat (arrhythmia) that might require treatment. Prevalence of palpitations and ECG abnormalities were determined and correlated with coronary risk factors and biochemical blood tests. Palpitations were present in 121 subjects (8.3\%) and cardiac arrhythmias were found in 183 subjects $(12.6 \%)$.

Palpitations may be caused by a wide range of different physiological and pathological conditions, clinicians tend to apply a number of instrumental investigations, laboratory tests, and specialist examinations, which are both time-consuming and costly.

In Unani system of medicine, heart is one of the three fundamental organs of the body. Heart is considered as the chief of vital organs and palpitation (Khafaqan) is described as critical for heart ailments. Palpitations are a common reason for urgent care visits and are very common in general population.
\end{abstract}

Keywords: Unani; Palpitation; Khafaqan; Heart

\section{Introduction}

Palpitation is characterized by an awareness of the beating of the heart. Patients commonly describe "pounding" or "fluttering" heart beats or reports a sensation that the heart is stopping or skipping beats. These symptoms may be caused by a change in the heart's rhythm or rate or by an increase in the force of its contractions. In many cases, this awareness reflects lack of competing sensory stimuli, such as when a person is lying in bed, unable to sleep [1].

Palpitation can be caused by cardiac arrhythmia as well as by other cardiac and non-cardiac conditions. A markedly enlarged left ventricle can cause awareness of heart beat by contact with the chest wall. Any condition associated with increased catecholamine levels can lead to palpitation both by increasing the forcefulness of cardiac conditions and by increasing the rate of premature beats [1].

Palpitation can be intermittent or sustained and regular or irregular. Patients with the complaint should be asked to describe their palpitations' onset, duration, associated symptoms, and the circumstances in which they occur. Abrupt onset and termination after several minutes may reflect a sustained ventricular or supraventricular tachyarrhythmia. Gradual onset and termination of a pounding heart beat is more consistent with sinus tachycardia. Palpitations are usually due to ectopic beats-namely Premature Atrial Contractions (PAC) and premature ventricular contractions (PVC) or due to Tachyarrhythmias.

\section{Etiology}

Many factors can cause cardiac palpitation. In the vast majority of cases, the cause may be cardiac or non-cardiac [2]:

- Cardiac causes: Conditions that cause marked left ventricular enlargement such as aortic regurgitation can cause an awareness of the heart beat that is sometimes positional. Presumably because of associated arrhythmias, hypertrophic cardiomyopathy, mitral valve prolapsed and other cardiac structural abnormalities are also associated with palpitations [3]. 
- Non-cardiac causes: Thyrotoxicosis, hypoglycemia, pheochromocytoma and fever. Drugs that can precipitate arrhythmias and palpitations include tobacco, coffee, tea, alcohol, epinephrine, ephedrine, aminophylline and atropine [3].

\section{Symptoms}

Palpitations are itself a symptom. They can be associated with an isolated "skipped beat" sensation or, if the palpitations are prolonged, there can be a feeling of fluttering or fullness in the chest. Palpitations are also more likely to reflect serious arrhythmias if they are associated with symptoms that suggest hemodynamic compromise, such as syncope, light headedness, dizziness or shortness of breath $[1,3]$.

Concept of palpitation (Khafaqan) in Unani system of medicine

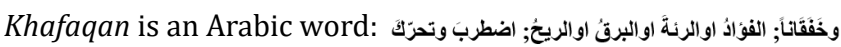

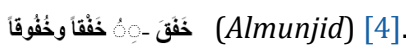

Avicenna, in his renowned book Canon of Medicine (Al-Qanoon Fil Tibb) has mentioned palpitation (Khafaqan) as follows [5]:

Palpitation (Khafaqan) is an irregular movement of heart. This may be caused by heart itself, pericardium, neighboring or associ-

$$
\text { | }
$$

\section{Figure}

ated organs. It occurs due to humoral derangement, simple morbid temperament, inflammatory conditions, dissolution, extrinsic factors or hypersensitivity. The humoral derangement may be sanguineous, phlegmatic, melancholic or bilious. It may also occur due to accumulation of gases" [5].

\section{Pathophysiology of palpitation (Khafaqan)}

The cause of palpitation (Khafaqan) includes pathology affecting cardiac structure, pericardium or its neighboring organs. Sometimes, palpitation (Khafaqan) is caused by Humoral matter (Madda-e-Khiltiyya) or Simple derangement of temperament (Sue-Mizaj Sada). Inflammation (Waram) and Dissolution (Inhelal-eFard) may also predispose palpitation (Khafaqan). In some circumstances, palpitation (Khafaqan) may also occur due to presence of foreign body or hypersensitivity.

Humoral matter (Maddah-e-Khiltiyya) may be [5-9]:

- $\quad$ Sanguine (Damaviyah),

- Moisten (Rutoobiyya),

- Melancholic (Saudaviyya),

- $\quad$ Airy (Riyahiyya).
Classification of palpitation (Khafaqan):

- Khafaqan Haar: It occurs due to simple hot derangement or predominance of sanguine (Dam) or yellow bile (Safra).

- Khafaqan Baarid: It occurs due to simple cold derangement or accumulation of phlegm (Balgham) within pericardium or accumulation of black bile (Saudav) within cardiac vessels.

- Khafaqan Yabis: It occurs due to simple dry derangement or accumulation of yellow bile (Safra).

Some other types of palpitation (Khafaqan) have also been mentioned in Unani classical literature which occurs due to weakness of heart, cardiac hypersensitivity and due to gastric involvement [6].

Manifestations of palpitation (Khafaqan) [7]:

Palpitation (Khafaqan) is manifested by:

- Engorgement of vessels,

- Laziness and lethargy (if caused by production of humoral matter (Madda-e-Khiltiyya),

- Cognitive disturbance (if there is involvement of black bile (Sauda),

- Fearfulness,

- Anxiety.

Management of palpitation (Khafaqan):

Principles of treatment:

- Evacuation (Istifragh)

- Dietary correction (Tadil-e-Ghiza)

- Moderation of food (Taltif-e-Ghiza)

- $\quad$ To tone up heart (Taqwitat-e-Qalb)

Palpitation (Khafaqan) may be managed by Evacuation (Istifragh) if it is caused by predominance of humours [5]. Evacuation (Istifragh) is done through emesis and purgation, if it is caused by gastric involvement [8]. Dietary correction (Tadil-e-Ghiza) will be made in all conditions of palpitation (Khafaqan) [5]. Moderation of food (Taltif-e-Ghiza) [5] and to tone up heart (Taqwitat-e-Qalb) is also highly recommended [5].

Following Unani drugs may be used in Khafaqan as Ilaj bil Dawa (Pharmacotherapy)

Single drugs [6]

\begin{tabular}{|c|l|}
\hline S. No & \multicolumn{1}{|c|}{ Name of Drugs } \\
\hline & Carrot (Daucus carota Linn.) \\
\hline & Aamla (Emblica officinalis Gaertn.) \\
\hline & Sandal (Santalum album Linn.) \\
\hline & Watermelon (Citrullus lanatus Thunb.) \\
\hline & Keora (Pandanus tectorius Soland.) \\
\hline & Apple (Malus-sylvestris Mill.) \\
\hline & Tabasheer (Bambusa arundinacea Retz.) \\
\hline & Aftimoon (Cuscuta epithymum) \\
\hline
\end{tabular}




\begin{tabular}{|l|l|}
\hline & Mushk (Musk) \\
\hline & wine grape (Vitis vinifera Linn.) \\
\hline & Kishneez (Coriandrum sativum Linn.) \\
\hline & Gaozaban (Onosma bracteatum) \\
\hline & Rose (Rosa damascena Mill.) \\
\hline & Kaddu (Cucurbita moschata) \\
\hline & Tukhm Rehan (Ocimum sanctum Linn.) \\
\hline & Toodri Surkh (Cheiranthus cheiri Linn.) \\
\hline & Zafran (Crocus sativus Linn.) \\
\hline
\end{tabular}

Table 1

Compound regimens

\begin{tabular}{|l|l|}
\hline S. No & \multicolumn{1}{|c|}{ Regimens } \\
\hline & $\begin{array}{l}\text { Ayarij-e-Rufas and Ayarij-e-Loghaziya in case of Kha- } \\
\text { faqan due to black bile (Sawda) [5]. }\end{array}$ \\
\hline & $\begin{array}{l}\text { Unnab (Zizyphus jujuba Linn.) 7 pieces, Zarishk (Berber- } \\
\text { is aristata DC.) 24 gm, Tamar Hindi (Tamarindus indica } \\
\text { Linn.) 72 gm with Arq Gaozaban (Onosma bracteatum) } \\
\text { and Arq Neelofar (Nymphaea alba Linn.) [6]. }\end{array}$ \\
\hline $\begin{array}{l}\text { Concoction of Badranjboya (Nepeta ruderalis Rott.), } \\
\text { Gaozaban (Onosma bracteatum) along with Gulqand } \\
\text { and Nastaran (Rosa alba Linn.) is very effective [6]. }\end{array}$ \\
\hline $\begin{array}{l}\text { Juice of Pomegranate (Punica granatum Linn.) along } \\
\text { with sugar, Keora (Pandanus odoratissimus Linn.) and } \\
\text { Bed Mushk (Salix caprea Linn.) [9]. }\end{array}$ \\
$\begin{array}{l}\text { Oral administration of Gaozaban (Onosma bracteatum) } \\
\text { 4.5 gm daily at bedtime regularly for few days is benefi- } \\
\text { cial [9]. }\end{array}$ \\
\hline $\begin{array}{l}\text { Peel of Ilaichi Kalan (Amomum subulatum Roxb.) is } \\
\text { soaked in water overnight and administered orally with } \\
\text { sugar in the morning [9]. }\end{array}$ \\
\hline $\begin{array}{l}\text { Oral administration of Tukhme Khashkhash (Papaver } \\
\text { somniferum Linn.) 12 gm in the morning along with cow } \\
\text { milk mixed with sugar [9]. }\end{array}$ \\
\hline $\begin{array}{l}\text { Liniment of Gul Nargis (Narcissus tazetta Linn.), Chameli } \\
\text { Uasminum officinale Linn.) with Roghan Sosan (Iris } \\
\text { ensata Thunb.) and Zambaq (Jasminum grandiflorum) is } \\
\text { used locally on the chest wall in Khafaqan [6]. }\end{array}$ \\
\hline
\end{tabular}

\section{Table 2}

Pharmacopeial Unani drugs

\begin{tabular}{|c|c|}
\hline S. No & Name of drugs \\
\hline & Khamira Abresham [6] \\
\hline & Khamira Sandal Sada [6] \\
\hline & Khamira Marwareed [6] \\
\hline & Khamira Khas [6] \\
\hline & Dawa-ul-Misk [6] \\
\hline & Safoof Lului [6] \\
\hline & Sharbat Sandal Tursh [9] \\
\hline & Qurs Kafoor [9] \\
\hline & Mufarreh Baarid [9] \\
\hline & Yaqooti [9] \\
\hline
\end{tabular}

Table 3

\section{Regimenal therapy (Ilaj bil-Tadbir)}

It is also one of the important modes of treatment in Unani system of medicine. Some of the following important and useful regimenal therapies for the management of palpitation (Khafaqan):

- Bloodletting (Fasd) is found to be effective in Khafaqan-eDamawi $[5,7]$.

- Emesis (Qai) and purgation (Ishaal) in Khafaqan due to gastric involvement [5,8].

\section{Dietary regimen}

Apart from drugs and regimenal therapies, diet also plays a promising role in the management of palpitation (Khafaqan).

Following diets are recommended in palpitation (Khafaqan) $[6,8]:$

- Goat milk

- Turnip

- Beet

- Carrot

- Apple

- Pineapple

- $\quad$ Egg

- Barley water

- Whey

- Meat soup.

Diets to be avoided in palpitation (Khafaqan) [6]:

- Flatulent diet (Aghziya Mubakhkhira)

- Smoking/alcohol

- Oily and fatty things

- Junk food.

\section{Conclusion}

Palpitation is a sign of a disease and is very common in general population. As we know Unani herbal medicine looks at diseases based on temperament and looks at every patient holistically very different from modern medicine. By using this aspect we can diagnose and treat patients and avoiding modern medical drug side effects. Concept of Palpitation and some useful Unani herbal drugs have been described here for the management of palpitation. These drugs and other regimens are natural, free form side effects, easily available and of course affordable.

\section{Bibliography}

1. Thomas H Lee. "Harrison's Principles of Internal Medicine". $16^{\text {th }}$ Edition Volume 1, Mc Graw Hill (2005): 81.

2. Goldman Lee and Schafer IA. "Cecil's textbook of medicine". $24^{\text {th }}$ Edition, Elsevier Saunders: 337.

3. Palpitations. "emedicinehealth" (2016).

4. Ajmunjid (Anonymous). Arabic to Arabic dictionary, $20^{\text {th }}$ Edition, Daru-al-Mashriq, Beirut, Lebanon (1969): 189.

5. Ibn Sina H. Al-Qanun fil Tibb, Volume III (Part I), (Arabic), Jamia Hamdard, New Delhi (1411): 409-415. 
6. Khan MA. Rumuz-e-Azam, Volume I, (Persian), CCRUM, New Delhi (2006) 300-331.

7. Nafis b. Iwaz. H, Sharah al Asbab wal Alamat, I, (Arabic), Matba Nami Nawal Kishor, Lucknow (1326): 275-276.

8. Ibn Zuhr. Kitab al Taysir fil Madawa wa al Tadbir, (Urdu translation), CCRUM, New Delhi (1986): 111-112.

9. Khan MA. Iksir-e-Azam, Volume II, (Persian), Matba Nami Nawal Kishor, Lucknow (1906): 280-312.

\section{Assets from publication with us}

- Prompt Acknowledgement after receiving the article

- Thorough Double blinded peer review

- Rapid Publication

- Issue of Publication Certificate

- High visibility of your Published work

Website: https://www.actascientific.com/

Submit Article: https://www.actascientific.com/submission.php

Email us: editor@actascientific.com

Contact us: +919182824667 